\title{
Rapid detection of Mycoplasma pneumoniae in clinical samples by the polymerase chain reaction
}

\author{
M. KAI, S. KAMIYA, H. YABE*, I. TAKAKURA*, K. SHIOZAWA† and A. OZAWA \\ Department of Infectious Diseases, Division of Host Defense Mechanism, * Department of Pediatrics, School of \\ Medicine, Tokai University, Bohseidai Isehara, Kanagawa 259-11, +Department of Microbiology, Shizuoka \\ Prefectural Institute of Public Health and Environmental Science, Shizuoka 420, Japan
}

\begin{abstract}
Summary. A DNA amplification method was used to detect Mycoplasma pneumoniae in clinical samples. M. pneumoniae $16 \mathrm{~S}$ ribosomal RNA gene sequences were selected as the amplification target region. The polymerase chain reaction (PCR) with purified DNA fragments as templates yielded an expected 88-bp fragment from $M$. pneumoniae but not from other Mycoplasma spp. nor from any of the other bacteria assayed. With this method, the 88-bp product specific for $M$. pneumoniae could be obtained from a minimum of $0.05 \mathrm{pg}$ of M. pneumoniae DNA. Subsequently this PCR technique was used for the detection of M.pneumoniae in throat-swab samples. Twenty-two of 30 culture-positive clinical samples gave positive results in the PCR test. Thirty-two culture-negative clinical samples and 33 samples from healthy volunteers, of which only one was culture-positive, gave negative results in the same PCR test. This PCR method is useful for the direct detection of $M$. pneumoniae in clinical samples.
\end{abstract}

\section{Introduction}

Mycoplasma pneumoniae is one of the causative agents of primary atypical pneumonia, especially in children and young adults. ${ }^{1.2}$ Epidemic infection with $M$. pneumoniae tends to occur at intervals of 3-5 years, but most childhood cases are mild. To avoid the unnecessary use of ineffective antibiotics, a rapid method of diagnosis is needed.

Serological methods such as the complement fixation test $(\mathrm{CFT})^{3}$ and indirect haemagglutination (IHA) $)^{4}$ are available for the diagnosis of $M$. pneumoniae infection, but these tests are time-consuming, have poor sensitivity and specificity, and diagnosis is often retrospective. Recently, enzyme-linked immunosorbent assays (ELISAs) with $M$. pneumoniae antigen or antibody have been developed ${ }^{5}$ and a rapid diagnostic method based upon DNA probe technology is also available. ${ }^{6-9}$ These are more specific and sensitive than the serological methods, but the minimum detectable number of cells is thought to be $10^{3}-10^{5} \mathrm{cfu}$ for the DNA probe method, and radioisotope detection is required.

The results of the DNA probe procedure suggested that the polymerase chain reaction (PCR) method might be useful for clinical diagnosis. ${ }^{10}$ This method amplifies a specific region of DNA by using two primers and Taq polymerase. Detection of $M$. pneu- moniae DNA by PCR has been reported by several groups, ${ }^{11.12}$ but has not yet been applied to human clinical samples. We report here the detection of $M$. pneumoniae in clinical throat-swab specimens by a PCR procedure.

\section{Materials and methods}

\section{Bacterial strains and growth conditions}

M. pneumoniae strains $\mathrm{FH}$ and MAC, $M$. buccale NIH-CH-20247, M. faucium ATCC 25293A, M. fermentans fermentans-C, $M$. genitalium $\mathrm{G} 37, M$. hominis PG21, M. orale ATCC 15539 and $M$. salivarium ATCC 14277 were kindly supplied by Dr M. Yoshikawa, The Institute of Medical Science, The University of Tokyo. They were grown on modified Hayflick's medium supplemented with horse serum $10 \%,{ }^{13}$ except for $M$. genitalium which was grown on medium supplemented with fetal bovine serum $10 \%$. After incubation for 3 5 days at $37^{\circ} \mathrm{C}$, they were subcultured in fresh medium. A diphasic medium ${ }^{14.15}$ was used for cultivation of clinical samples to isolate $M$. pneumoniae. The bacterial strains investigated are listed in table 1.

\section{Clinical samples}

The throat-swab samples were obtained from paediatric outpatients presenting with symptoms of cough and fever at several hospitals in Shizuoka prefecture, 
Table I. Bacterial species used for evaluation of the specificity of the PCR detection method

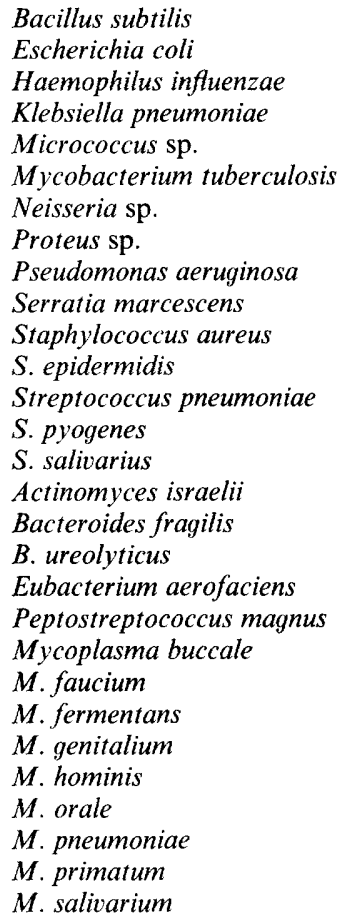

Japan. Negative control samples were collected from healthy volunteers. Swabs were washed out in $1 \mathrm{ml}$ of PPLO broth by vortex mixing. For detection of $M$. pneumoniae by cultivation, $0.1 \mathrm{ml}$ of the suspension was inoculated into the diphasic medium and incubated at $37^{\circ} \mathrm{C}$ for $2-3$ weeks. The remainder of the sample was used for DNA extraction.

\section{Extraction of DNA}

DNA was extracted as described by Stauffer $e t$ al. ${ }^{16}$ Briefly, $10 \mathrm{ml}$ of broth-grown mycoplasmas were centrifuged at $15000 \mathrm{~g}$ for $10 \mathrm{~min}$ at $4^{\circ} \mathrm{C}$ and the supernate was discarded. The pellet was suspended in $100 \mu$ of $0.15 \mathrm{M} \mathrm{NaCl}, 0 \cdot 1 \mathrm{M}$ EDTA solution, and then $400 \mu \mathrm{l}$ of lysis solution $(0.1 \mathrm{M} \mathrm{NaCl} ; 0 \cdot 1 \mathrm{M}$ Tris- $\mathrm{HCl}$, pH 8.0 ; SDS $1 \%$ ) was added. The solution was then frozen at $-80^{\circ} \mathrm{C}$ for $10 \mathrm{~min}$, and incubated at $60^{\circ} \mathrm{C}$ for $5 \mathrm{~min}$ after thawing. The lysate was extracted gently, twice, with an equal volume of phenol:chloroform (1:1). DNA was incubated at $37^{\circ} \mathrm{C}$ for $2 \mathrm{~h}$ with RNAase A (Sigma) $50 \mu \mathrm{g} / \mathrm{ml}$. The DNA was precipitated with two volumes of ice-cold absolute ethanol, rinsed twice with ethanol $70 \%$, and after drying by evaporation, suspended in $100 \mu$ of TE $(10 \mathrm{mM}$ Tris- $\mathrm{HCl}, \mathrm{pH} 8 \cdot 0 ; 1 \mathrm{~mm}$ EDTA). The concentration of DNA was measured with a spectrophotometer (Beckman Du-65, Beckman Instruments Inc., Fullerton, USA). For the extraction of bacterial DNA, cells grown in LB broth (Bacto-Trypton $1 \%$, yeast extract $1 \%, \mathrm{NaCl} 0.5 \%$ ) were harvested by centrifugation at $10000 \mathrm{~g}$ for $1 \mathrm{~min}$ followed by the same procedure as described above. For throat swabs, the PPLO broth $(1 \mathrm{ml})$ rinse was centrifuged at $15000 \mathrm{rpm}$ for $10 \mathrm{~min}$ at $4^{\circ} \mathrm{C}$, and the pellet was suspended in $400 \mu$ of $15 \mathrm{~mm}$ EDTA, $0 \cdot 1 \mathrm{M} \mathrm{NaCl}$, and vortex mixed. To this was added $50 \mu \mathrm{l}$ of $0 \cdot 1 \mathrm{M} \mathrm{NaCl}, 0 \cdot 1 \mathrm{M}$ Tris- $\mathrm{HCl}$ (pH 8.0), SDS $8 \%$, and then the solution was frozen. Further extraction was performed as described above. Finally the samples were suspended in $10 \mu \mathrm{l}$ of TE, and $2 \mu \mathrm{l}$ of the suspension was subjected to the PCR assay.

\section{DNA amplification}

Oligonucleotide primers were synthesised by a DNA synthesiser (Model 380B, Applied Biosystems Inc., Foster City, USA). Amplifications were performed in a thermal cycler TSR-300 (Iwaki Glass Co., Tokyo, Japan) by the method described by Saiki et al. ${ }^{17}$ The PCR reaction mixture consisted of $50 \mu \mathrm{l}$ of $200 \mu \mathrm{M}$ dNTPs, $5 \mu$ of $10 \times$ Taq polymerase reaction buffer (Stratagene, La Jolla, USA) (100 mM Tris- $\mathrm{HCl}$, pH 8.3; $500 \mathrm{~mm} \mathrm{KCl} ; 15 \mathrm{~mm} \mathrm{MgCl}_{2}$; gelatin $0 \cdot 1 \% \mathrm{w} / \mathrm{v}$ and other stabilisers), an appropriate amount (1-10 $\mu \mathrm{l})$ of template DNA, $1 \mu \mathrm{M}$ of each primer, 2.5 units of Taq polymerase (Stratagene), and water. To avoid evaporation, two drops of mineral oil were poured on top of the reaction mixture. The temperature programme was as follows: $94^{\circ} \mathrm{C}$ for $120 \mathrm{~s}$ for initial denaturation, $94^{\circ} \mathrm{C}$ for $60 \mathrm{~s}$ for cycle denaturation, $62^{\circ} \mathrm{C}$ for $30 \mathrm{~s}$ for annealing, $74^{\circ} \mathrm{C}$ for $30 \mathrm{~s}$ for extension. After 35 cycles of incubation, the mixture was incubated at $74^{\circ} \mathrm{C}$ for $60 \mathrm{~s}$ for additional extension. The $10 \mu \mathrm{l}$ of PCR products were analysed by agarose $4 \%$ gel electrophoresis in Tris-borate EDTA buffer (Nusieve GTG: Agarose $\mathrm{ME}=3: 1$ ) (FMC BioProducts, Rockland, USA). The gel electrophoresis was performed at $100 \mathrm{~V}$ for $2 \cdot 5-3 \mathrm{~h}$. DNA fragments were visualised by UV illumination after staining with ethidium bromide $0.5 \mu \mathrm{g} / \mathrm{ml}$ for $30 \mathrm{~min}$ at room temperature.

\section{Oligonucleotide primers for PCR}

Oligonucleotide primers were selected from a variable region of the $M$. pneumoniae $16 \mathrm{~S}$ rRNA genome ${ }^{18}$ as shown in fig. 1 . The sense primer designated $\mathrm{Mp}-8$ consisted of 22 oligonucleotides and the anti-sense primer designated Mp-6 consisted of 26 oligonucleotides. The extra primer, $\mathrm{Mp}-1$, for three-primer

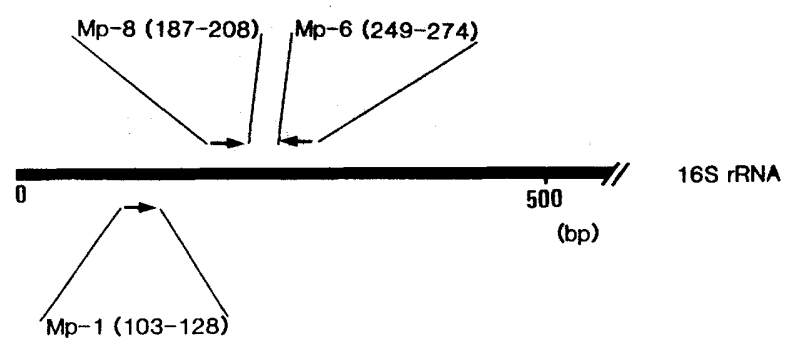

Fig. 1. Oligonucleotide primers on $16 \mathrm{~S}$ rRNA gene of $M$. pneumonicte used for the detection of $M$. pneumoniae by PCR. 
PCR, was a 26 oligonucleotide sense primer. These oligonucleotide sequences were 5'-CAAAGTTGAAAGGACCTGCAAG-3' for Mp-8, 5'-ATTGCCTTGGTAGGCCGTTACCCCAC-3' for $\mathrm{Mp}-6$, and 5'ACACGTATCCAATCTACCTTATAATG-3' for $\mathrm{Mp}-1$. The fragment amplified by Mp-8 and Mp-6 was $88 \mathrm{bp}$, and that amplified by $\mathrm{Mp}-1$ and $\mathrm{Mp}-6$ was $172 \mathrm{bp}$.

\section{Three-primer PCR}

To confirm that the amplified DNA originated from M. pneumoniae, three primer PCR was performed as described previously ${ }^{19}$ with Mp-8, Mp-6 and Mp-1. When PCR with these three primers produced simultaneous amplification products of $88 \mathrm{bp}$ and $172 \mathrm{bp}$ it could be assumed that these had originated from the target region.

\section{Results}

\section{Specificity of PCR for $M$. pneumoniae}

No DNA amplification was detected by this method when non-mycoplasma bacterial DNA was examined (data not shown). The results of PCR of eight Mycoplasma species are shown in fig. 2. The specific 88-bp amplification product was produced from $M$. pneumoniae strains MAC and FH (fig. 2, lanes 8 and 9) but not from other Mycoplasma spp. (fig. 2, lanes 2-7, 10 and 11). The three-primer method produced two specific bands, 88 and $172 \mathrm{bp}$, indicating that the 88-bp product of the amplification of $\mathrm{Mp}-8$ and $\mathrm{Mp}-6$ originated from $M$. pneumoniae (fig. 2, lane 12). A 50 -bp fragment sometimes appeared in negative controls. This fragment seemed to be a primer dimer and affected neither the specificity nor the sensitivity of the PCR for $M$. pneumoniae.

\section{Sensitivity of PCR for $M$. pneumoniae}

The sensitivity of the PCR method was examined by

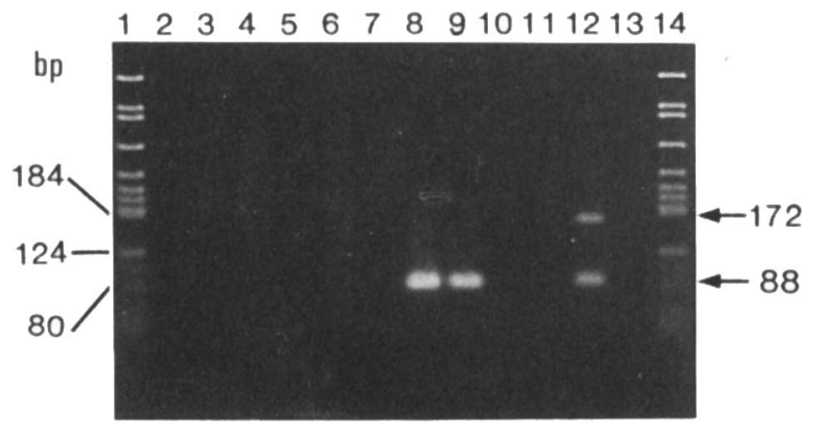

Fig. 2. Specificity of the PCR method for the detection of $\boldsymbol{M}$. pneumoniae: $10 \mathrm{ng}$ of DNA extracted from Mycoplasma spp. was used as a template in PCR. Lanes 1 and 14, marker DNA (Ha'llIdigested pAT153 DNA): 2. $M$. huccale; 3. $M$. faucium: 4, $M$ formentans: 5, M. genilalium: 6, M. hominis: $7, M$. orale: 8. M phetmoniae FH strain: 9, $M$. pnewmoniae MAC strain: 10. $M$ prinatum: 11. $M$. salirarium: 12. M. pneumoniae FH strain (amplified by three-primers P(R): 13, no template. serial dilutions of purified DNA from $M$. pneumoniae FH (fig. 3). PCR produced a visible 88-bp fragment from $0.05 \mathrm{pg}$ of template DNA indicating that $c .100$ organisms could be detected. When the amplified products were hybridised with a complementary probe, the sensitivity was raised c. 100-fold (data not shown).

Detection of $M$. pneumoniae in throat-swab samples by $P C R$

Seventy-two throat swabs were obtained from patients suspected of having $M$. pneumoniae infection. Thirty samples were culture-positive for $M$. pneumoniae, 32 were negative and 10 gave indeterminate results due to bacterial contamination. In the PCR tests, the 88-bp fragment was produced from 22 of 30 culture-positive samples, two of 32 culture-negative samples and three of 10 contaminated samples (table II). In contrast, none of the specimens from healthy controls produced the 88-bp band, although one sample was culture-positive. Representative PCR results are shown in fig. 4 .

\section{Discussion}

A PCR procedure was developed for detection of $M$. pneumoniae in clinical throat swabs. Two PCR

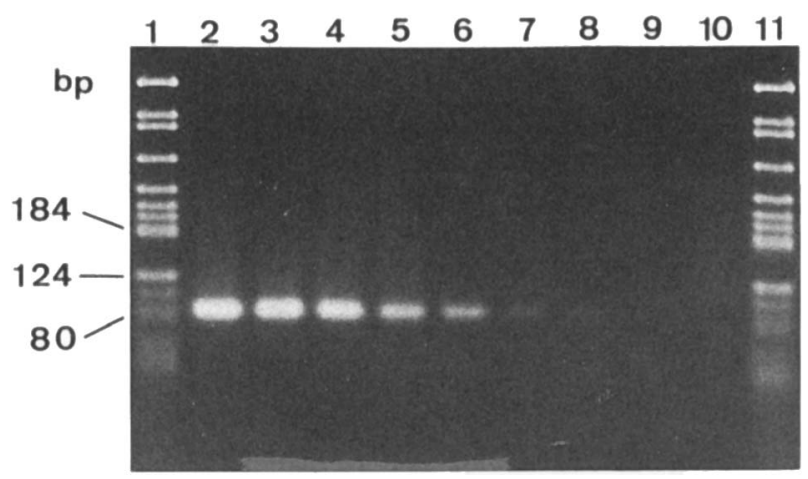

Fig. 3. Sensitivity of PCR for detection of $M$. pneumoniac: various doses $(0.01 \mathrm{pg}-10 \mathrm{ng}$ ) of $M$. pneumoniae DNA (FH strain) were used as templates in the PCR. Lanes 1 and 11, marker DNA (HaellIdigested pAT153 DNA); 2, $10 \mathrm{ng} ; \mathbf{3}, 1 \mathrm{ng} ; 4,100 \mathrm{pg} ; 5,10 \mathrm{pg} ; \mathbf{6}$, $1 \mathrm{pg} ; 7.0 .1 \mathrm{pg} ; 8,0.05 \mathrm{pg} ; 9.0 .01 \mathrm{pg} ; 10$, no template.

Table II. Evaluation of PCR and cultivation methods for detection of $M$. pneumoniae in throat swabs from patients and healthy volunteers

\begin{tabular}{|c|c|c|c|}
\hline $\begin{array}{l}\text { Throat swab } \\
\text { source }\end{array}$ & $\begin{array}{c}\text { Culture } \\
\text { result }\end{array}$ & $\begin{array}{c}\text { Number of } \\
\text { samples tested }\end{array}$ & $\begin{array}{l}\text { Number of } \\
\text { samples positive } \\
\text { in PCR }\end{array}$ \\
\hline & $(+$ & 30 & 22 \\
\hline \multirow[t]{2}{*}{ Patient } & $\{-$ & 32 & 2 \\
\hline & $1 C^{*}$ & 10 & 3 \\
\hline Healthy & $1+$ & 1 & 0 \\
\hline volunteer & $\{-$ & 32 & 0 \\
\hline
\end{tabular}

* Culture result was not reliable due to contamination with other bacteria. 
$\begin{array}{llllllllllllll}1 & 2 & 3 & 4 & 5 & 6 & 7 & 8 & 9 & 10 & 11 & 12 & 13\end{array}$

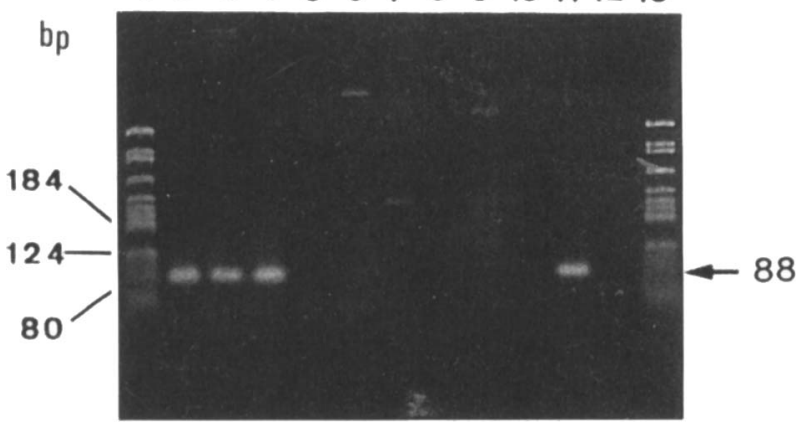

Fig. 4. Detection of $M$. pneumoniae by PCR in throat swabs obtained from patients suspected to have $M$. pneumoniae infection and from healthy volunteers. Lanes 1 and 13, marker DNA (HaeIIIdigested pAT153 DNA); 2-4, throat swabs from patients (culturepositive); 5-7, throat swabs from patients (culture-negative); 8-10, throat swabs from healthy volunteers (culture-negative); 11, $M$. pneumoniae (FH strain) DNA, $10 \mathrm{ng} ; \mathbf{1 2}$, no template.

primers, $\mathrm{Mp}-6$ and $\mathrm{Mp}-8$, were selected from a variable region of the 16S rRNA gene which has specific sequences in many bacterial strains. ${ }^{18,20,21}$ The target 88-bp fragment was amplified in tests with $M$. pneumoniae $\mathrm{FH}$ and MAC but not with other Mycoplasma spp. such as $M$. buccale, $M$. faucium, $M$. fermentans, $M$. genitalium, $M$. hominis, $M$. orale, $M$. primatum and M. salivarium, as reported previously. ${ }^{9-12}$ The $88-\mathrm{bp}$ fragment was not amplified in tests with other bacteria. Three-primer PCR was also performed with an additional primer $\mathrm{Mp}-1$. The production of two amplified products of 88 and $172 \mathrm{bp}$ indicated that the $88-\mathrm{bp}$ product originated from $M$. pneumoniae DNA.

The PCR method amplified the 88-bp fragment from $0.05 \mathrm{pg}$ DNA of $M$. pneumoniae, indicating that the PCR can theoretically detect $100 \mathrm{M}$. pneumoniae cells. The high sensitivity and specificity of mycoplasma PCR demonstrated in this study were similar to results reported by others. ${ }^{11.12}$ Bernet et al. ${ }^{11}$ reported that PCR can detect $10^{2}-10^{3}$ organisms, and Jensen et al ${ }^{12}$ estimated a detection limit of $<40 \mathrm{cfu}$.

We applied this PCR method to the detection of $M$. pneumoniae in clinical specimens. The 88 -bp band was amplified with 22 of 30 culture-positive throat samples. It is unclear why eight culture-positive samples did not give a positive PCR result. This may have been due to poor recovery of DNA during the extraction procedure. Two of 32 culture-negative clinical samples gave a positive reaction in PCR, indicating a relatively high specificity of PCR in comparison with cultivation techniques. It is possible that our cultivation technique with a diphasic medium ${ }^{14.15}$ was not specific for the detection of $M$. pneumoniae. The cultivation method depends on a colour change due to acid produced by growth of $M$. pneumoniae, but the growth of contaminating bacteria can also change the colour of the medium. No positive PCR result was obtained with 33 samples from healthy volunteers.

Jensen et al ${ }^{12}$ used PCR to detect mycoplasmas in simulated clinical samples. Similarly, Bernet et al. ${ }^{11}$ used the PCR method for biological samples (throat swabs) obtained from hamsters experimentally infected with $M$. pneumoniae. The present study is the first to use PCR for the detection of $M$. pneumoniae in human clinical samples (throat swabs). The sensitivity and specificity of PCR were estimated to be $73 \%$ and $94 \%$, respectively. Further evaluation of this PCR method is needed if the test is to be used routinely in clinical practice.

We are grateful to Dr M. Yoshikawa, The Institute of Medical Science, The University of Tokyo, for supplying Mycoplasma strains. This work was supported in part by a Grant-in-Aid for Scientific Research (A) from the Ministry of Education, Science and Culture.

\section{References}

1. Eaton MD, Meiklejohn G, van Herick W. Studies on the etiology of primary atypical pneumonia: a filtrable agent transmissible to cotton rats, hamsters and chick embryos. $J$ Exp Med 1944; 79: 649-668.

2. Denny FW, Clyde WA, Glezen WP. Mycoplasma pneumoniae disease: clinical spectrum, pathophysiology, epidemiology, and control. J Infect Dis 1971; 123: 74-92.

3. Kenny GE, Grayston JT. Eaton pleuropneumoniae-like organism (Mycoplasma pneumoniae) complement-fixing antigen : extraction with organic solvents. J Immunol 1965; 95 : 19-25.

4. Dowdle WR, Robinson RQ. An indirect hemagglutination test for diagnosis of Mycoplasma pneumoniae infections. Proc Soc Exp Biol Med 1964; 116: 947-950.

5. Jacobs E, Bennewitz A, Bredt W. Reaction pattern of human anti-Mycoplasma pneumoniae antibodies in enzyme-linked immunosorbent assays and immunoblotting. J Clin Microbiol 1986; 23 : 517-522.

6. Göbel UB, Geiser A, Stanbridge EJ. Oligonucleotide probes complementary to variable regions of ribosomal RNA discriminate between Mycoplasma species. J Gen Microbiol 1987; 133 : 1969-1974.

7. Hyman HC, Yogev D, Razin S. DNA probes for detection and identification of Mycoplasma pneumoniae and Mycoplasma genitalium. J Clin Microbiol 1987; 25: 726-728.

8. Dular R, Kajioka R, Kasatiya S. Comparison of Gen-Probe commercial kit and culture technique for the diagnosis of Mycoplasma pneumoniae infection. J Clin Microbiol 1988; 26: $1068-1069$.

9. Kleemola SRM, Karjalainen JE, Räty RKH. Rapid diagnosis of Mycoplasma pneumoniae infection: clinical evaluation of a commercial probe test. $J$ Infect Dis 1990; 162: 70-75.

10. Saiki RK, Scharf S, Faloona F et al. Enzymatic amplification of $\beta$-globin genomic sequences and restriction site analysis for diagnosis of sickle cell anemia. Science $1985 ; 230: 1350$ 1354.

11. Bernet C, Garret M, de Barbeyrac B, Bebear C, Bonnet J. Detection of Mycoplasma pneumoniae by using the polymerase chain reaction. $J$ Clin Microbiol 1989; 27: 24922496.

12. Jensen JS, Søndergård-Andersen $\mathbf{J}$, Uldum SA, Lind $\mathbf{K}$ Detection of Mycoplasma pneumoniae in simulated clinical samples by polymerase chain reaction. APMIS 1989; 97 : 1046-1048.

13. Chanock RM, Hayflick L, Barile MF. Growth on artificial medium of an agent associated with atypical pneumonia and its identification as a PPLO. Proc Natl Acad Sci USA 1962; 48: 41-49.

14. Kraybill WH, Crawford YE. A selective medium and color test for Mycoplasma pneumoniae. Proc Soc Exp Biol Med 1965; 118: 965-970.

15. Smith CB, Chanock RM, Friedewald WT et al. Mycoplasma 
pneumoniae infections in volunteers. Ann $\times Y$ Acad Sci 1967: $143: 471-483$.

16. Stauffer GV. Plamann MD. Stauffer LT. Construction and expression of hybrid plasmids containing the Escherichia coli gll. A genes. Gene 1981: 14: 63-72

17. Saiki RK. Gelfand DH, Stotfel S et al. Primer-directed enzymatic amplification of DNA with a thermostable DNA polymerase. Science 1988: 239: 487-491.

18. Weisburg WG. Tully JG. Rose DL et al. A phylogenetic analysis of the mycoplasmas: basis for their classification $J$ Bacteriol 1989: 171: 6455 6467.
19. Kai M. Kamiya S. Sawamura S, Yamamoto T, Ozawa A. Simplified method for confirmation of PCR products. Nucleic Acids Res 1991; 19: 4562.

20. Noller HF, Woese CR. Secondary structure of $16 \mathrm{~S}$ ribosomal RNA. Science $1981 ; 212: 403-411$

21. Gray MW, Sankoff D. Cedergren RJ. On the evolutionary descent of organisms and organelles: a global phylogeny based on a highly conserved structural core in small subunit ribosomal RNA. Nucleic Acids Res 1984; 12:5837-5852. 